\title{
Faith in Rights: the Struggle Over Same- Sex Adoption in the United Kingdom
}

\section{Carl. F. Stychin*}

\section{Introduction}

Over the past decade of Labour government in the United Kingdom (U.K.), the regulation of sexual orientation through law has frequently been explained by its supporters through a narrative of progress and even emancipation. The most recent junction in this journey came in 2007, with the coming into force of the Equality Act (Sexual Orientation) Regulations on 30 April 2007. ${ }^{1}$ These Regulations contain measures prohibiting discrimination on grounds of sexual orientation in the provision of goods, facilities and services, education, the use and disposal of premises, and the exercise of public functions. ${ }^{2}$

The Regulations must be set within the wider context of the still fairly new Equality Act 2006, ${ }^{3}$ which created the Commission for Equality and Human Rights (the enforcement body for the $A c t$ ), and which replaces the piecemeal system of equality rights protection previously found in the Equal Opportunities Commission, the Commission for Racial Equality, and the Disability Rights Commission. The Equality Act 2006 outlawed discrimination on the grounds of religion or belief, and imposed duties related to sexual discrimination on persons performing public functions, but left for a later day the issue of sexual orientation discrimination in the provision of goods and services.

Understood in this context, and given the fact that legal change addressing this issue came about by statutory instrument rather than primary legislation, ${ }^{4}$ the sexual orientation $R e g u$ - lations might be interpreted as a mere tidying up exercise. However, this would be a misinterpretation of events. The issue of sexual orientation was held over to be dealt with by secondary legislation, in part because of the perceived complexity and controversial nature of the issue and, perhaps, in the hope that extensive public debate and discussion would be avoided. ${ }^{5}$ Ultimately, the Regulations were approved by Parliament in March 2007, and entered into effect on 30 April 2007.

Even before the Regulations were laid before Parliament, a storm of controversy erupted which raised wide-ranging concerns related to rights, sexuality, religion, beliefs, secularism, the limits of tolerance of minorities, as well as to how minorities are socially constructed. This article focuses on parliamentary and print media representations of the issues at stake. Central to the controversy was the future status of Catholic adoption agencies, which are subject to the Regulations in that they provide a service to prospective parents. ${ }^{6}$ The widely discussed question was whether those agencies should be exempt from a duty to consider same-sex couples on an equal basis in the application of the "best interests of the child" test, in placing children for adoption.

The issue assumed a symbolic importance far beyond its practical relevance. It was widely agreed that there were many avenues open to same-sex couples wishing to pursue adoption aside from the Catholic agencies and, intuitively, it seemed unlikely that many same-sex couples 
would be adamant on pursuing adoption only through a Catholic agency. Nevertheless, samesex adoption came to stand for a larger principle concerning the extent to which faith-based groups, which receive public subsidy, could be exempted from anti-discrimination legislation when providing a public service. Conversely, the principle was expressed as concerning the extent to which the discourse of equality and gay rights trumped the sincerely held faith-based views of a minority, views which were being expressed through the provision of adoption services. Not surprisingly, the adoption issue also fuelled well-worn discourses around the best interests of children, same-sex parenting, and the heterosexual family as the "gold standard" in the raising of children. ${ }^{7}$

\section{Constructing the Minority Group}

Opposition to the sexual orientation Regulations was articulated through a mixture of old and new tropes. While my particular interest in this article is the new discourses around secularism and the rights of religious minorities to exist in a secular society - a characterization which I want to problematize - there is still plenty of space for longstanding old arguments which centre on children. Not only do these discourses focus upon the way in which the best interests test should be applied, but also on other claims familiar to those who have studied anti-gay rhetoric. ${ }^{8}$ For example, much attention was paid to the family run bed-and-breakfast establishment, and the alleged right of proprietors to turn away same-sex couples because the proprietors' faith would not allow them to create opportunities for those couples to engage in sodomy within the family home (a home which, of course, had been turned into a commercial operation). ${ }^{9}$ This example allowed both sides to demonstrate the manipulability of the binaries of public/private, commercial/residential, and home/work, in support of their arguments. It also gave rise to interesting references to the act/identity distinction related to sexual orientation. Couples would be turned away, not because of who they are, but because of what they would potentially do (on the assumption that the act of doing sodomy is an inevitable result of being given an opportunity to practice it). ${ }^{10}$ The language of child protection also figured prominently in this example, appearing in claims defending children in hypothetical families from the infiltration of homosexuals into the family home. Such language resonates with very old tropes concerning pollution and infection. ${ }^{11}$

In both political and media debate, considerable time was also given over to schools. Baroness O'Cathain, for example, recounted that:

a pro-gay group . . . is already going around the country telling schools that the regulations mean they have to normalise homosexuality to seven-year-olds and read gay fairy tales in the classroom. ${ }^{12}$

Here, the longstanding trope concerning the promotion of homosexuality through education reappears; this trope has a pedigree dating back to the now repealed section 28 of the Local Government Act, ${ }^{13}$ which prohibited the promotion of homosexuality by local authorities as a "pretended family relationship." 14 Opponents of the Regulations feared that the letter of the law, as well as the "climate of fear"15 created by the Regulations, would force schools, including faith-based schools, to promote homosexuality through gay sex education classes. In this way, faith-based schools would be prevented from promoting sexual monogamy through the institution of marriage.

However, there was also a new focus in popular and parliamentary debate, which turned on faith-based, conscientious objectors to homosexuality - those who provide goods and services to the public. In this argument, the wedding photographer and the caterer become the oft-cited examples of those who might feel morally compelled to turn away lesbian or gay clients. ${ }^{16}$ The objectors to homosexuality are consistently constructed as a minority group, and an increasingly oppressed minority, which will be forced to act against its genuinely and deeply held religious beliefs. In the process, the minority's rights are trumped (and trampled upon) in the service of the rights of "well organised and intolerant lobbies,"17 who have the backing of political elites. While supporters of the sexual orientation Regulations describe the 
law as achieving a balance among conflicting rights; for opponents, the law does precisely the opposite - it throws the relationship between equality and freedom of religion out of balance, and does so in such a way as to counter the historic Englishness of protections for liberty, speech, and the freedom of groups to practice their beliefs. As one opponent of the Regulations puts the point: "It is a development entirely at variance with our well rooted tradition of religious tolerance and liberty." ${ }^{18}$ In this way, the law ignores the interests of an increasingly persecuted minority and puts innocent, morally upstanding individuals in fear of prosecution. ${ }^{19}$ Thus, "religions are now seen not primarily as beneficiaries of rights of protection from the state, as subjects enjoying religious freedom, but as potential sources of human rights breaches. Religion is a problem." ${ }^{20}$

\section{The Silenced Majority}

At the same time, critics of the Regulations suggest that the law has also ignored the voices of the (silenced) majority, which occupy the genuine "middle ground" of politics. The sexual orientation Regulations are "a weapon promoting discrimination against both majority and minority religious faiths," ${ }^{21}$ which have been marginalized by the actions of political elites seeking to find favour with a well organized, articulate, and powerful lesbian and gay constituency. This middle ground is constructed through "common sense," but common sense which also includes the practice of disclaiming homophobia. ${ }^{22}$ That is, opponents of progressive gay rights legislation increasingly make clear - and this has always been true to some extent - that they are not homophobic. Indeed, many commentators and politicians go further and are at pains to point out that they have supported gay rights in the past, but that this is a step too far. ${ }^{23}$ While these critics proclaim their support for anti-discrimination legislation in employment, possibly even for civil partnership legislation (probably because it is not marriage in name), and occasionally even support antidiscrimination legislation with respect to goods and services in general, the moral or common sense objection to gay rights should also be re- spected and protected. Scepticism regarding the value of same-sex adoption provides one such example of common sense which is self-evidently true, but which has been silenced by the totalitarianism of gay rights. ${ }^{24}$ Thus, critics seek to defend both the rights of a minority, as well as the views of the majority. They can also portray themselves as defenders of the faith, and all faiths, by pointing to both the established Church and to the country's Christian heritage (which is being eroded by the government), as well as to the importance of a multifaith, multicultural society. Finally, critics are the defenders of the best interests of children who are otherwise sacrificed to a political correctness, which protects the rights of lesbians and gays as consumers of adoption services.

In response, proponents of the Regulations rely heavily on the rhetoric of equality rights, fairness, and balance: "the measures we have brought forward protect the rights of individuals and organisations to hold religious beliefs while also ensuring that everyone lives a life free from harmful discrimination." ${ }^{25}$ Analogies are drawn between sexual orientation, race, and gender, all of which are deserving of the same level of legal protection: "I start from a very firm foundation: there is no place in our society for discrimination." ${ }^{26}$ The need for compliance with international obligations is also mentioned. ${ }^{27}$ The discourse of child welfare, moreover, is countered on its own discursive terrain. Arguments are made that the Regulations will protect gay youth from bullying in schools, protect children of gay parents from discrimination in education, and could ensure that children, who would otherwise not be adopted, will find loving homes with same-sex couples (although the gold standard of heterosexual parenting remains largely untroubled in these arguments). Many supporters of the Regulations also bolster their positions by proclaiming their own Christian faith, which is articulated through competing, progressive principles of tolerance, fairness, and social justice. ${ }^{28}$

But this discursive battle becomes abstracted to a further degree in the debates, as it is increasingly reformulated in terms of a struggle between secularism and faith. Opponents cas- 
tigate the Regulations as yet further evidence of a secular ideology, which has become the dominant and guiding principle of the Labour government and, indeed, of political elites more generally. In this narrative, it is rights discourse, and specifically the Human Rights Act $1998,{ }^{29}$ which is central to the undermining of freedom and pluralism, and which has created a literal perversion of "right reason." Through the protection of human rights, a secular society is being forced upon the population; this secular society is one in which religion is relegated to a narrow private sphere, closeted from public display. The Regulations do provide for exceptions for religious organizations. However, for their opponents, these exceptions only protect the narrow sphere of worship (that is, religious identity), rather than the "doing" of religion in the public realm (the practice). As Julian Rivers argues, "at best, this seems to create a category of 'tolerated' religion which may be permitted between consenting adults in private, but which ideally would be eradicated." 30 Therefore, in an unlikely twist, the distinction between act and identity - often deployed to regulate sexual identities and practices - now gets knowingly reversed by opponents of the Regulations in defence of the right to practice religion. ${ }^{31}$ By contrast, proponents argue that the religious exceptions ensure that a balancing of rights is achieved, and the key distinction is the line between the religious and the commercial. Once that line is crossed, religious groups must act in a nondiscriminatory fashion. Moreover, faithbased schools, it is argued, can continue to promote monogamous heterosexuality within the institution of marriage, while providing emotional support to all children. ${ }^{32}$

\section{Secularism as Fundamentalism}

Despite the exceptions for religion in the Regulations, opponents remain adamant that secularism has become the dominant ideology and, indeed, they claim that it is the new religion of the political class, which has trampled over and silenced all others. In making this claim, ambiguity is apparent as to whether all religions have been unfairly treated, which is sometimes claimed, or whether, more spe- cifically, it is the country's Christian tradition which is under constant threat from the secular. At this point, there are interesting analogies that can be drawn with the way in which Christianity is constructed as under threat from multiculturalism. The focus on Catholic adoption agencies, and the extent to which this issue resulted in extensive joint lobbying of government by Catholic bishops and the Church of England hierarchy, underscores the extent to which the issue was seen as an attack on Christianity. This is further supported by the way in which secularism has been constructed, not only as the new religion, but as a fundamentalist religion, in which thinly veiled comparisons are drawn to Islam. ${ }^{33}$ As Rivers warns:

[I]t seems that a new moral establishment is developing, which is being imposed by law on dissenters. Those filling public offices are well advised to avoid challenging it, and even the most measured and reasoned public questioning of its truth can trigger formal investigations. This new orthodoxy masks itself in the language of equality, thus refusing to discuss its premises and refusing to articulate its conception of the good. ${ }^{34}$

Even Catholics on the progressive left, in defence of gay rights, resort to language that is not altogether dissimilar: "in the post-socialist age, non-faith based progressives are deadly serious about imposing their liberalism." 35

In this regard, the debate provides a flavour of the way in which secularism is invoked in the U.K. as the sign of a contemporary ideological struggle. On this point, Judith Butler has recently addressed how secularism is deployed in the admittedly very different political culture of France to interrogate how it works to bolster anti-Islamic "progressive" politics. ${ }^{36}$ In doing so, she also makes the general argument that "secularism does not so much succeed religion sequentially, but reanimates religion as part of its ideas of culture and civilization." ${ }^{37}$ I would argue that the controversy around the Regulations could be interpreted in support of this thesis. Rather than the totalitarian imposition of a secular ideology upon a faith-based population - with the replacing of religion by a new faith (in liberal rights) - we find instead a "mix of 
religious and secular ideals,"38 in which secularism does not succeed religion but coexists, perhaps uneasily, with it.

Butler argues, and here she mirrors the views of many opponents of the Regulations, that "securalism has a variety of forms, and many of them involve forms of absolutism and dogmatism that are surely as problematic as those that rely on religious dogma." ${ }^{39}$ However, in the U.K. the evidence of the absolutism of secularism is far from compelling. Stewart Motha makes this very point in relation to the juxtaposition of liberalism and the construction of Islamic fundamentalism, when he argues that "the repression of the religious as the condition of modern politics reveals itself to be the unfinished enterprise threatened by the eternal return of religion." ${ }^{40}$ Motha refers to a British culture which can claim to be both "secular in outlook" and, at the same time, "committed to Christian institutions, political and juridical formations." ${ }^{31}$

There is much evidence for Motha's claim in the events surrounding the Regulations. A superficial examination of the structure of the Regulations themselves reveals that faith is embedded within the law in the form of exemptions. Religious faith is taken to be synonymous with the integrity of belief, and serves to exempt the application of the law. ${ }^{42}$ While opponents may argue that the exemptions are drawn too narrowly, the relevant point is that they are drawn on the basis of religion rather than, for example, on the basis of sincerely held belief. Moreover, parliamentary debates are virtually devoid of any criticism of faith-based homophobic views. ${ }^{43}$ Instead, supporters of the Regulations argue that when religious groups offer a service to the public, they have crossed a line (the religious/commercial, public/private binary) such that the application of the law is appropriate. ${ }^{44}$ But there is little discursive space for a critique of religion (especially of Christianity), or for a discussion of the offensiveness of some religious doctrine. ${ }^{45}$ Furthermore, faith-based schools, which remain high on the government's agenda, are still allowed to promote marriage and heterosexuality as the most desirable way of life. ${ }^{46}$ The one notable exception to this uncritical acceptance of religion can be found in the speech of the openly gay and Muslim member of the House of Lords, Lord Alli, who makes clear that discriminatory views grounded in religious texts are unacceptable in a liberal democracy, and not just when religious actors enter the public, commercial sphere:

When I read the Koran, it tells me in some passages that I must kill Jews. If I believe strongly enough that I must kill Jews, does that mean that I have the right to say, 'Exempt me from legislation because I believe it strongly enough. Let me discriminate against Jews, at least, because I believe it strongly enough and it is written in the Koran?'47

However, what further undermines the claim of the absolutism of secularism in the way in which it is deployed by opponents of the Regulations, is the place given to religious voices in political debate in the U.K. The Catholic Church and Church of England played prominent roles around the same-sex adoption question, facilitated by the membership of Church officials in the House of Lords, hardly a secular institution. ${ }^{48}$ But the political terrain was further complicated by the religious beliefs of prominent Labour politicians, and the way in which religion, particularly for politicians of the centre-left, has been partially closeted from the public sphere. Most famously, Tony Blair's admission of his deeply held religious beliefs and his conversion to Catholicism immediately after leaving office, combined with his openly admitted fear of being labelled a "nutter" for his faith, underscore the complexities of religion for the Labour Party. ${ }^{49}$ The then Secretary of State for Communities and Local Government, Ruth Kelly, is well known as a practising Catholic and member of the Opus Dei organization, and rumour had it that she had difficulty supporting the Regulations, despite having responsibility for social cohesion and inclusion as part of her government portfolio. ${ }^{50}$ Even the Civil Partnership Act 2004, ${ }^{51}$ although often described as a further sop to the lesbian and gay communities, prevents the forming of civil partnerships in religious buildings, and ensures that marriage is restricted to the union of one man and one woman. ${ }^{52}$

The need for discretion that seems to be felt 
by some British politicians - with respect to Roman Catholicism at least - could be seen as evidence that practising Christians have been forced into a sphere of privacy - even secrecy - by the dominance of secularism on the left. Equally, however, the need for discretion might be the result of age-old stereotypes regarding Catholics, secret societies, and foreign allegiance to the Vatican. I would suggest that it indicates, at a minimum, a complex and contested relationship between religions, but more crucially between Christianity and politics in Britain today, which is informed by the historic roles played by the established Church and Roman Catholicism. ${ }^{53}$

Kate Nash has argued that human rights politics in the U.K. is best described in terms of a "communitarian rights culture," in which the values of dialogue, compromise, and "the attempt to reach and sustain agreement over conflict and divergence in understandings of social relationships" is paramount. ${ }^{54}$ She finds that the Civil Partnership Act exemplifies this culture, in which the divisive debates which have characterized struggles over same-sex marriage have been largely absent from British political life. In my view, there is much merit to this position, but the sexual orientation Regulations demonstrate the precariousness of such communitarian approaches to rights, as well the potential for rights struggles to produce polarized positions. Although the Regulations carve out religious exemptions, and are characterized by proponents as a sensible, reasonable balancing of equality rights and religious freedom in a democratic society, the language of balance and compromise always leaves open the possibility of further struggle over the proper balance of competing rights, and over the question of whether society has gone too far: "this legislation effects a rearrangement of discriminatory attitudes and bias to overcompensate and skew the field the other way." 55 In this moment, rights are constructed as a zero-sum game. ${ }^{56}$ They favour individualism over "the rights of voluntary societies." 57 Given that the Human Rights Act itself was a skilful attempt at balancing fundamental rights and the principle of parliamentary supremacy, leaving inevitable rights compromises to be resolved in the political realm, it is hardly surpris- ing that British rights discourse has become a site of struggle, and that debates over human rights have been described as a quagmire. ${ }^{58}$ Furthermore, it may be that the issue of same-sex adoption adds a particularly combustible fuel to the politics of rights because of the complex relationship between children, parents, and sexuality. ${ }^{59}$ In part, this is because it is far too easy to move from the rights of consumers of services to the right to possess and perhaps "consume" our children. ${ }^{60}$ Such arguments leave supporters of the Regulations to rely on their faith in the judicial application of the best interests test to ensure that children's interests are adequately protected.

\section{Concluding Thoughts}

To conclude, the Critical Legal Studies movement long ago taught us to be cautious about putting too much of our faith in rights. ${ }^{61}$ The experience of rights struggles around sexuality over the past decade reveals that the language of rights lends itself to anti-gay arguments which not only deploy rights talk, but which can mirror the arguments advanced by progressive actors. The debate over same-sex adoption highlights this point. Opponents of the sexual orientation Regulations can construct faith-based groups as disenfranchised, oppressed minorities which are increasingly forced to exercise discretion, and keep their beliefs in the private sphere, closeted away from public view. According to them, the being of religion may be their right, but the doing of religion is subject to intense legal regulation by the state, undermining the core of their freedom. In this narrative, rights are being undermined by the secularist totalitarianism of the political elites and the fanatics of the lesbian and gay movement. Simultaneously, rights discourse is deployed in the name of the common sense majority and on behalf of vulnerable children needing protection from rights seekers themselves.

However, the very fact that the Regulations have come into force may suggest cause for optimism, and the increasing marginalization of voices of opposition. On the other hand, the need felt by government to postpone application of the Regulations to Catholic adoption 
agencies until 31 December 2008, pending further analysis of their potential impact, suggests that the supposed triumph of secularism is far from complete.

\section{Notes}

* School of Law, University of Reading, United Kingdom.

1 Equality Act (Sexual Orientation) Regulations, S.I. 2007/1263 (BAILII) [Regulations].

2 The offence is created by section 3 of the Regulations. Section 3(1) states: "For the purposes of these Regulations, a person ("A") discriminates against another ("B") if, on grounds of the sexual orientation of $\mathrm{B}$ or any other person except $\mathrm{A}, \mathrm{A}$ treats B less favourably than he treats or would treat others (in cases where there is no material difference in the relevant circumstances)."

3 (U.K.), 2006, c. 3 (BAILII).

4 The issue of employment discrimination on the basis of sexual orientation had previously been dealt with by the Employment Equality (Sexual Orientation) Regulations S.I. 2003/1661 (BAILII) in 2003, which implement the European Community Equal Treatment Directive 2000/78/EC of 2000 .

5 In fact, little opportunity to debate the question was made available in Parliament. However, the choice to use secondary legislation was itself subject to some fierce criticism, and not only from critics of the substance of the Regulations.

6 By comparison, in some states in the United States statutory restrictions remain in place prohibiting the adoption of children by lesbians and gays. See Carlos A. Ball, "The Immorality of Statutory Restrictions on Adoption by Lesbians and Gay Men" (2007) 38 Loyola University Chicago Law Journal 379.

7 On heterosexuality as the gold standard of parenting, see Judith Stacey \& Timothy J. Biblarz, "(How) Does the Sexual Orientation of Parents Matter?” (2001) 66 American Sociological Review 159 at 162.

8 See e.g., Didi Herman, The Anti-Gay Agenda: Orthodox Vision and the Christian Right (Chicago: University of Chicago Press, 1997).

9 Section 6 of the Regulations, however, contains an exception in relation to the family home if the premises do not accommodate more than two households or six individuals (in addition to the landlord and his/her near relative).

10 See e.g., Lord Mackay: "They must be prepared to allow them, if appropriate, to use the facilities that they provide for the purpose of homosexual practice. That is quite different from other types of discrimination." U.K., House of Lords, Official Report, session 2 (2007), vol. 688, col. 184 (9 January 2007) (Lord Mackay of Clashfern).

11 See e.g., Viscount Brookeborough: "This is about having people among your family ... the Government are introducing into a family something from which it is surely the right of the parents to protect their children until they are at an age at which they can decide for themselves." Supra note 10 at col. 194-5.

12 U.K., House of Lords, Official Report, session 4 (2007), vol. 690, col. 1298 (21 March 2007).

13 Local Government Act 1988 (U.K.), 1988, c. 9 (BAILII).

14 For a discussion of the discourses surrounding section 28 and its repeal, see Carl F. Stychin, Governing Sexuality: The Changing Politics of Citizenship and Law Reform (Oxford: Hart Publishing, 2003); see also Momim Rahman, "The Shape of Equality: Discursive Deployments During the section 28 Repeal in Scotland" (2004) 7 Sexualities 150.

15 Supra note 10 at col. 192 (Lord Tebbit).

16 See e.g.,

They make it possible for homosexual activists to sue people who disagree with a homosexual lifestyle because of their religious beliefs. Bed and breakfast owners and Christian old people's homes will be sued for not giving a double bed to homosexual civil partners. Wedding photographers will be made to pay compensation for not taking bookings for civil partnership ceremonies. Christians in business could even be sued for sharing their faith with customers. Worst of all, they require religious organisations to choose between obedience to God and obedience to the state.

Ibid. at col. 180 (Lord Morrow).

17 Supra note 12 at col. 1305 (Lord Anderson of Swansea).

18 Ibid. at col. 1302 (Lord Bishop of Southwell and Nottingham); see also Julian Rivers, "Law, Religion and Gender Equality" (2007) 9 Ecclesiastical Law Journal 24 at 52: "Freedom of religion in English law has not simply been about the freedom to believe and manifest that belief in worship and doctrine, but about the construction of a plurality of protected social and material spaces in which believers could live faithfully to their religion."

19 See e.g., Lord Tebbit: "these regulations would leave perfectly innocent people in fear of legal action by the fanatical wings of the lesbian and gay pressure groups," supra note 15. 
20 Rivers, supra note 18, at 35.

21 Melanie Phillips, "A law that turns sexual tolerance into tyranny" Daily Mail (19 June 2006).

22 The practice of disclaiming homophobia is discussed by Burridge in the context of opposition to the repeal of section 28 of the Local Government Act: see Joseph Burridge, "I am not Homophobic But . . .': Disclaiming in Discourse Resisting Repeal of Section 28" (2004) 7 Sexualities 327. The practice of disclaiming is not a new phenomenon: see Anna Marie Smith, New Right Discourse on Race and Sexuality: Britain, 19681990 (Cambridge: Cambridge University Press, 1994).

23 See Phillips, supra note 21: "We have therefore exchanged one deep intolerance for another."

24 See e.g., Lord Blackwell, supra note 12 at col. 1320:

we should allow adoption agencies to have, as one of the criteria that they use in selecting parents, the preference, if that can be achieved, for having two parents of opposite sex.

25 Communities and Local Government, Guidance on New Measures to Outlaw Discrimination on Grounds of Sexual Orientation in the Provision of Goods, Facilities and Services (London: Department for Communities and Local Government, 2007) at 5.

26 Tony Blair, "No place for discrimination in society," online: 10 Downing Street <http://www. number10.gov.uk/output/Page10869.asp $>$. Supra note 10 at col. 202 (Lord Lester of Herne Hill).

28 See e.g., Lord Lester of Herne Hill, supra note 12 at col. 1323: "the principles of human rights are universal ... they derive not only from the secular Enlightenment but from all the great religions." See also, Baroness Andrews, supra note 10 at col. 1328: "there is no polarity between Christianity and our joint commitment to put an end to discrimination,"

29 (U.K.), 1998, c. 18 (BAILII).

30 Rivers, supra note 18 at 36.

31 See Rivers, supra note 18 at 46 :

[exceptions] tend to address what are centrally 'religious' activities, and they do not address peripheral difficulties that might be experienced by religious people trying to work in a changed ethical environment.

32 See Department for Education and Employment, Sex and Relationship Education Guidance (Nottingham: DfEE Publications, 2000) at 4:

pupils should be taught about the nature and importance of marriage for family life and bringing up children. But the government recognises ... that there are strong and mutually supportive relationships outside marriage. Therefore pupils should learn the significance of marriage and stable relationships as key building blocks of community and society.

33 See e.g., Carla Powell, "Beware the Taleban of Tolerance," The Spectator (10 February 2007).

34 Rivers, supra note 18 at 52.

35 Conor Gearty, "Sex and the Secular Liberal" The Tablet (10 February 2007) 9.

36 Judith Butler, "Sexual Politics, Torture, and Secular Time” (2008) 59 British Journal of Sociology 1.

37 Ibid at 14.

38 Ibid.

39 Ibid at 13.

40 Stewart Motha, "Liberal Cults, Suicide Bombers, and other Theological Dilemmas" (2009) 5 Journal of Law, Culture and the Humanities in press, unpublished manuscript on file with author.

41 Ibid.

42 See e.g., section 14(3) of the Regulations:

Nothing in these Regulations shall make it unlawful for an organisation to which this regulation applies, or for anyone acting on behalf of or under the auspices of an organisation to which this regulation applies - (a) to restrict membership of the organisation, (b) to restrict participation in activities undertaken by the organisation or on its behalf or under its auspices, (c) To restrict the provision of goods, facilities or services in the course of activities undertaken by the organisation or on its behalf or under its auspices, or (d) to restrict the use or disposal of premises owned or controlled by the organisation, in response of a person on the ground his sexual orientation." Section 14(3) applies, by virtue of s 14(1) "to an organisation the purpose of which is - (a) to practice a religion or belief, (b) to advance a religion or belief, (c) to teach the practice or principles of a religion or belief, (d) to enable persons of a religion or belief to receive any benefit, or to engage in any activity, within the framework of that religion or belief.

43 See e.g., Lord Rooker, supra note 10 at col. 209:

"The regulations have been drafted to allow for the views and opinions of religious groups and organisations to be protected where it is necessary to comply with doctrine."

44 See e.g., Baroness Andrews supra note 12 at col. 1291:

The Government have provided an exemption for religious or belief organisations, and those acting under their auspices, where that is necessary to avoid conflicting either with the doctrine of the organisation or the strongly held beliefs of a significant number of a religion's followers. But where religious 
organisations choose to step into the public realm and provide services to the community, either on a commercial basis or on behalf of and under contract with a public authority, that surely brings with it a wider social responsibility to provide those services for the public as they are, in all their diversity, and not to pick and choose who will benefit or who will be served.

Lord Rooker, supra note 10 at col. 208: "It is not the Government's intention to attack religious ethos."

Supra note 32 at 8: "Schools of a particular religious ethos may choose to reflect that in their sex and relationship education policy."

47 Supra note 12 at col. 1317. However, some opponents do make the claim that religion is not homophobic: "Christians and other faiths across the country have a gracious and loving attitude towards their neighbours, regardless of their orientation," ibid. at col. 1317 (Lord Browne of Belmont); "The Catholic Church is not homophobic," ibid. at col. 1306 (Baroness Morris of Bolton).

48 This increasing vocal role of religious leaders in openly lobbying politicians has not abated since the Regulations were passed, and can be seen graphically in the recent Human Fertilisation and Embryology Bill debates in 2008, in which Catholic bishops exhorted Catholic Members of Parliament to oppose the legislation on the grounds of conscience. Indeed, at the time of the sexual orientation Regulations, a Roman Catholic Cardinal "felt about to write a letter to the Prime Minister and the entire Cabinet setting out 'Catholic teaching about the foundations of family life,"' Gearty, supra note 35 at 8.

49 "Blair feared faith 'nutter' label" BBC News (25 November 2007) online BBC News < http://news. bbc.co.uk/1/hi/uk_politics/7111620.stm $>$.

50 "Kelly's views on gays questioned" BBC News (9 May 2006) online BBC News <http://news.bbc. co.uk/2/hi/uk_news/politics/4756399.stm >.

51 (U.K.), 2004, c. 33 (BAILII).

52 See Carl F. Stychin, "Not (Quite) a Horse and Carriage: The Civil Partnership Act 2004" (2006) 14 Feminist Legal Studies 79.

53 The hostile reactions to the Archbishop of Canterbury's reflections on Sha'ria Law suggest that issues of law, religion and politics remain a potent combination.

54 Kate Nash, "Human Rights Culture: Solidarity, Diversity and the Right to be Different" (2005) 9 Citizenship Studies 335 at 346.

55 Supra note 12 at col. 1309 (Archbishop of York). 56 Ibid. at col. 1298 (Baroness O'Cathain): “The
Government have taken the view that gay rights trump religious rights ... A citizen's right to manifest sexual orientation is absolute, but the right to manifest religious belief is not."

57 Ibid. at col. 1304 (Lord Pilkington of Oxenford).

58 Ibid. at col. 1311 (Archbishop of York).

59 The issue has also been legalized through a case before an Employment Appeal Tribunal, concerning whether a magistrate could refuse to follow the Regulations in relation to adoption, on the basis of a moral objection: McClintock $v$. Department of Constitutional Affairs (2007) WL 3130902, Appeal No. UKEAT/0223/07/CEA at p. 62 . His arguments failed at the original tribunal as well as on appeal. The Tribunal concluded:

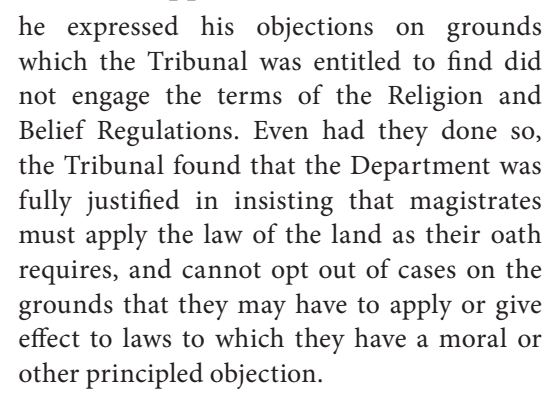

By way of contrast, an Employment Tribunal has recently ruled that the failure to exempt a registrar from performing civil partnership registrations, because the requirement to do so clashed with her Christian beliefs, amounted to both direct and indirect discrimination on the grounds of religion and belief: Ladele $v$ London Borough of Islington (2008) Case No. 2203694/2007.

60 Of course, the tragic irony in this narrative is the historic role of Christian denominations in the abuse of children (especially those in care), which for so long remained shielded in a protected sphere of privacy and secrecy.

61 See e.g., Joel Bakan, Just Words: Constitutional Rights and Social Wrongs (Toronto: University of Toronto Press, 1997); Judy Fudge \& Harry Glasbeek, "The Politics of Rights: A Politics with Little Class" (1992) 1 Social \& Legal Studies 45. 